\title{
PERCANGGAHAN PENDAPAT ASPEK TATABAHASA: PERBANDINGAN ANTARA BAHAN RUJUKAN BAHASA MELAYU
}

\author{
Inconsistency of Opinion in Grammar Aspect: Comparative between Malay \\ Language Reference Materials \\ Wong Shia $\mathrm{Ho}^{1}$ \\ wsh@ipbl.edu.my \\ Yeo Swee King ${ }^{2}$ \\ yeosweeking@yahoo.com \\ Institut Pendidikan Guru Kampus Batu Lintang, Kuching, Sarawak ${ }^{1}$ \\ Sekolah Kebangsaan Kenyalang, Kuching, Sarawak ${ }^{2}$
}

\begin{abstract}
ABSTRAK
Kertas kajian ini memperlihatkan percanggahan pendapat yang berlaku dalam bahan rujukan Bahasa Melayu. Percanggahan pendapat tentang sesuatu aspek tatabahasa ditonjolkan melalui perbandingan maklumat dalam bahan rujukan itu sendiri atau dengan bahan rujukan lain. Kajian ini menggunakan persampelan bertujuan bagi mendedahkan fenomena yang diterokai. Analisis kandungan dilakukan terhadap bahan rujukan yang dipilih berdasarkan kedekatan dan kredibilitinya sebagai bahan rujukan kepada pengguna bahasa. Hasil kajian mendapati bahawa percanggahan pendapat tentang tatabahasa bukan sahaja berlaku antara bahan rujukan yang berlainan malah percanggahan juga berlaku dalam bahan rujukan itu sendiri. Selain itu, kertas ini juga memperlihatkan kesan percanggahan tersebut kepada pengguna bahasa melalui kaedah tinjauan terhadap 23 orang guru di sekolah tentang penggunaan kata bantu dalam ayat. Bagi menghadapi percanggahan pendapat ini, pelbagai pandangan dikemukakan agar keseragaman dan ketepatan maklumat dapat diberikan kepada pengguna bahasa bagi mengelakkan kekeliruan bahasa berlaku dalam kalangan mereka.
\end{abstract}

Kata Kunci: Bahasa Melayu Baku; Percanggahan Pendapat; Bahan Rujukan

\begin{abstract}
This paper presents an inconsistency of opinion in the Malay Language reference material. Conflict of opinion on a particular aspect of grammar is highlighted through the comparison of information in the reference material itself or with other reference materials. This study uses sampling aims to expose the explored phenomena. Content analysis is done on selected reference materials based on their proximity and credibility as references to language users. The findings show that inconsistencies in grammar not only occur between different reference materials but also discrepancies in the reference material itself. In addition, this paper also shows the impact of the discrepancy to language users through a survey of 23 teachers in the school on the use of auxiliary verbs in sentences. In response to this contradiction, various views are presented to enable uniformity and accuracy of information to be provided to language users in order to avoid confusion among the speakers.
\end{abstract}

Keywords: Standard Malay Language; Dissent, References Materials

\section{PENGENALAN}

Penekanan terhadap bahan rujukan yang berwibawa amatlah penting dalam pembelajaran bahasa. Melalui peribahasa, "bagaimana acuan, begitulah kuihnya", dapat dilihat hubungan yang rapat antara 
pembentuk dengan hasilnya. Dalam hal pembelajaran bahasa, "pembentuk" ini bukan sahaja dapat dikaitkan guru-guru khususnya guru Bahasa Melayu, malah bahan rujukan Bahasa Melayu juga mempengaruhi pembelajaran bahasa seseorang. Hal ini jelas dinyatakan oleh Abdul Hamid Mahmood (2002) bahawa buku-buku Bahasa Melayu yang baik dan bermutu dapat menjadi contoh yang baik kepada pelajar. Pada masa ini, para pengguna Bahasa, termasuk pelajar-pelajar, tidak lagi hanya bergantung kepada buku-buku yang disyorkan oleh Kementerian Pendidikan Malaysia sahaja, malah mereka mudah mendapat bahan rujukan lain. Dalam bahan-bahan rujukan tersebut, sudah tentu para penulis mempunyai pendirian dan pandangan yang ada kalanya tidak sama tentang sesuatu penggunaan bahasa. Kepelbagaian pendapat dalam kalangan penulis buku turut mempengaruhi pemikiran pembaca. Hal ini diperkukuh oleh pernyataan Abdul Hamid Mahmood (2002) bahawa media cetak dan media elektronik boleh mempengaruhi penguasaan Bahasa Melayu para pelajar kerana mereka beranggapan bahawa semua yang dicetak atau disiarkan adalah betul.

Dalam konteks kajian ini, bahan rujukan yang berkualiti dari segi bahasanya dilihat amat penting bagi memastikan pengguna bahasa mendapat maklumat yang tepat tentang Bahasa Melayu baku. Jika bahan rujukan menyediakan maklumat yang betul dan tekal, nescaya pengguna bahasa akan mendapat maklumat yang betul dan menggunakannya secara tekal juga. Begitu juga sebaliknya berlaku jika maklumat yang didedahkan tidak tekal dan mengelirukan pengguna bahasa tersebut. Kajian ini dilakukan bagi memperlihatkan unsur-unsur percanggahan bahasa yang berlaku dan kesan-kesannya kepada penggunaan bahasa. Kajian ini juga mengemukakan cadangan pengurangan percanggahan pendapat dalam penghuraian sesuatu rumus tatabahasa.

\section{PERNYATAAN MASALAH}

Proses pembelajaran bahasa tidak dapat lari daripada melakukan kesilapan atau kesalahan. Hal ini jelas dinyatakan oleh Corder (1981) bahawa semua orang sama ada secara sengaja atau tidak akan melakukan kesalahan bahasa. Walau bagaimanapun, kajian ini berpendapat bahawa pernyataan tersebut tidaklah bermaksud bahawa seseorang pengguna bahasa sememangnya boleh menggunakan bahasa yang tidak mengikut hukum atau rumus yang betul kerana penggunaan bahasa tidak baku sebenarnya dapat dielakkan. Oleh itu, pelbagai kajian dilakukan berkaitan dengan kesalahan penggunaan Bahasa Melayu dalam kalangan pengguna bahasa di negara ini. Menurut Wong (2015), kajian tentang kesalahan bahasa khususnya terhadap pelajar pelbagai peringkat pengajian telah banyak dilakukan oleh penyelidik bahasa. Antara yang terkini ialah kajian oleh Zaliza Mohamad Nasir (2017), Salinah Jaafar \& Rohaidah Haron (2016), Wan Zaliha Wan Othman \& Amanah Mohd. Noor (2015); Nur Syafiqah Mohd Isa (2014), Yong \& Vijayaletchumy Subramaniam (2012) dan Siti Baidura Kasiran (2011). Kesalahan bahasa yang dikaji oleh mereka selalunya dikaitkan dengan faktor persekitaran atau latar belakang pengguna bahasa tersebut, antaranya faktor pengaruh ibunda, jantina, tempat tinggal dan sebagainya. Jarang sekali kita dapat melihat perbincangan tentang perkaitan tahap penguasaan bahasa dengan bahan bacaan sepertimana yang dikatakan oleh Abdul Ghalib Yunus (2003) dan Abdul Hamid Mahmood (2002) bahawa kekeliruan bahasa berlaku disebabkan oleh ahli bahasa yang pakar dalam bidang tatabahasa BM yang tidak sepakat dalam sesuatu hal yang berkaitan dengan tatabahasa. Kamus Dewan dan Buku Tatabahasa juga didapati tidak selari dari aspek bahasa. Ketidaksepakatan yang dimaksudkan oleh Abdul Ghalib Yunus (2003) tersebut selaras dengan pendapat Soo (dalam Chew, 2008) bahawa para pakar BM di Malaysia sentiasa bercanggah pendapat menyebabkan masyarakat umum rasa keliru (Percanggahan bermaksud "bertentangan pendapat, perkara atau keputusan dan lain-lain" Kamus Dewan, 2015:243).

Sebagai tambahan kepada faktor kekeliruan bahasa yang disebutkan itu, Zaharani Ahmad (2007) pula menyatakan bahawa kekeliruan dalam pengggunaan bahasa berpunca daripada percanggahan antara nahu pegangan yang bersifat preskriptif yang diajarkan di sekolah dengan nahu praktis yang diperoleh melalui pengalaman dan pengetahuan penutur sendiri. Menurut Zaharani Ahmad (2007), nahu praktis ialah nahu yang mencerminkan penggunaan sebenar bahasa dalam masyarakat seperti yang terhimpun di dalam korpus bahasa. Apabila berlaku percanggahan antara rumus tatabahasa dengan nahu praktis. Maka dua kesimpulan boleh dikemukakan: 
i. Korpus merakamkan bentuk-bentuk bahasa yang salah kerana kekhilafan dan kejahilan penuturnya.

ii. Kedua, rumus mendeskripsikan huraian yang salah kerana kesilapan dan ketidaktuntasan penahunya.

Bagi mencari jawapan kepada "sejauh manakah percanggahan yang dimaksudkan oleh kajiankajian terdahulu ini berlaku dalam BM?", kajian ini menyelami fenomena tersebut dengan melakukan penelitian terhadap bahan-bahan rujukan yang dianggap berwibawa, paling dekat dan mudah dicapai oleh pengguna bahasa.

\section{OBJEKTIF KAJIAN}

Secara umumnya, kajian ini dijalankan bagi memperlihatkan percanggahan bahasa dalam bahan rujukan Bahasa Melayu. Secara khususnya, objektif kajian adalah untuk:

i. membincangkan percanggahan pendapat aspek tatabahasa dalam bahan rujukan itu sendiri.

ii. membincangkan percanggahan pendapat aspek tatabahasa antara bahan rujukan.

iii. memperlihatkan kesan-kesan percanggahan pendapat aspek tatabahasa kepada pengguna bahasa.

\section{PERSOALAN KAJIAN}

i. Apakah jenis percanggahan pendapat aspek tatabahasa dalam bahan rujukan itu sendiri?

ii. Apakah jenis percanggahan pendapat aspek tatabahasa antara buku rujukan?

iii. Apakah kesan percanggahan pendapat aspek tatabahasa terhadap pengguna bahasa?

\section{SOROTAN LITERATUR}

Perbincangan tentang tatabahasa sering dikaitkan dengan penggunaan bahasa yang tidak betul mengikut rumusnya oleh pelbagai pihak sama ada institusi awam atau swasta, para pelajar pelbagai peringkat pengajian sehinggalah orang perseorangan. Kesalahan bahasa yang dilakukan sering dikaitkan dengan jenis-jenis kesalahan, faktor penyebab kesalahan berlaku, dan tanggungjawab pelbagai pihak untuk menangani isu tersebut. Sebagai contoh, kajian oleh Mohammed Zin Nordina, Mohd Taib Ariffinb, Khairul Azam Baharic \& Siti Munirah Md. Zukhid (2013) tentang penggunaan bahasa pada papan perniagaan institusi awam mendapati bahawa kesalahan dari segi ejaan, kesalahan frasa dan kesalahan morfologi berada pada tahap yang tinggi berdasarkan kajian yang telah dijalankan. Mereka mengaitkan kesalahan tersebut dengan sebab kelemahan dalam penguasaan Bahasa Melayu, sikap sambil lewa dan tidak meletakkan kepentingan untuk memartabatkan Bahasa Melayu. Kajian bahasa terhadap sektor awam pula telah dilakukan oleh Junaini Kasdan, Nor Suhaila Che Pa \& Mohd Syamril Aklmar Che Kassim (2015). Kajian yang dilakukan oleh mereka terhadap penjawat awam di Universiti Teknikal Malaysia mendapati bahawa masih terdapat kelemahan penggunaan bentuk morfologi dan sintaksis dalam kalangan responden kajian.

Kajian tentang kesalahan bahasa oleh pelajar pelbagai peringkat pengajian juga banyak dilakukan. Siti Baidura Kasiran (2011) juga telah melakukan kajian tentang kesalahan tatabahasa dalam kalangan 40 orang pelajar asing di sebuah institusi pengajian tinggi awam melalui penelitiannya terhadap hasil penulisan karangan mereka dan dapatan soal selidik daripada guru/pensyarah yang mengajar kursus Bahasa Melayu untuk Pelajar Asing di universiti tersebut. Hasil kajian mendapati kesalahan tatabahasa disebabkan gangguan bahasa ibunda, sikap pelajar dan keadaan persekitaran bahasa di universiti. Zaliza Mohamad Nasir (2017) turut melakukan kajian yang hampir sama dengan kajian Siti Baidura Kasiran (2011), beliau memfokuskan kajian tentang kesalahan tatabahasa yang 
dilakukan oleh pelajar Indonesia. Kajian beliau ini yang melakukan penelitian terhadap penulisan ilmiah mendapati bahawa faktor yang menyebabkan kesalahan bahasa ialah kekurangan pengetahuan tentang sistem bahasa kedua dan kemahiran penggunaan bahasa mengikut konteks.

Salinah Jaafar \& Rohaidah Haron (2016) pula melakukan kajian terhadap pelajar luar negara yang menuntut di Akademi Pengajian Melayu, Universiti Malaya melalui penelitian terhadap skrip jawapan peperiksaan pelajar. Menurut Salinah Jaafar dan Rohaidah Haron, penguasaan Bahasa Melayu yang asas sering menjadi masalah dalam proses pembelajaran dan pengajaran dalam kalangan pelajar. Kajian tersebut juga mendapati bahawa pelajar melakukan kesilapan bahasa khususnya dari aspek morfologi, sintaksis dan mekanikal. Yong \& Vijayaletchumy Subramaniam (2012) juga telah melakukan kajian tentang kesilapan dalam pembelajaran Bahasa Melayu oleh 75 orang pelajar asing di universiti tempatan di negara ini. Ujian penulisan dan pemerhatian selama lapan minggu digunakan dalam proses pengumpulan data. Sebanyak 182 kes kesilapan ortografi/ejaan telah dikenal pasti dan digolongkan kepada lima aspek mengikut tahap kesukaran penguasaan yakni kata angka asas, diikuti kata tanya, kata komunikasi asas, kata ganti nama diri, dan akhirnya kata sapaan. Jenis kesilapan fonologi yang paling kerap direkodkan ialah penukaran huruf dengan huruf lain. Kesilapan berkenaan berbeza antara pelajar mengikut latar belakang demografi, khasnya negara asal dan bahasa ibunda.

Selain beberapa kajian yang melibatkan responden pelajar asing. Kajian tentang penguasaan tatabahasa terhadap pelajar tempatan turut dilakukan oleh pengkaji bahasa. Nur Syafiah Mohd Isa (2014) telah melakukan kajian terhadap penguasaan Bahasa Melayu sebagai bahasa Kedua dalam kalangan pelajar etnik Cina di sekolah menengah persendirian Cina. Kajian tersebut adalah untuk mengenal pasti faktor penguasaan Bahasa Melayu pelajar etnik Cina dan objektif kedua adalah melihat sejauh mana masalah penguasaan pelajar tersebut dari segi pertuturan dan penulisan. Dalam kajian kes yang dijalankan melalui temu bual, didapati bahawa faktor sikap, persekitaran, motivasi instrumental, bahasa ibunda, dan factor keluarga telah dikenal pasti berkaitan dengan penguasaan Bahasa Melayu pelajar etnik Cina. Para pelajar didapati menghadapi masalah penguasaan Bahasa Melayu dari segi pertuturan dan penulisan melibatkan kesalahan tatabahasa. Walau bagaimanapun, dapatan kajian oleh Liew, Yahya, Abdul Rashid Jamian (2003) sedikit berbeza dengan dapatan kajian Nur Syafiqah Mohd Isa. Dalam kajian tentang kesalahan bahasa dalam karangan pelajar Cina di sekolah menengah, didapati bahawa kesalahan dari morfologi, sintaksis, pemerengganan, mekanis dan penanda wacana oleh pelajar disebabkan oleh faktor jantina, dan aliran pengajian dan tidak ada kaitan dengan tempat tinggal dan taraf sosioekonomi keluarga.

Selain kajian di institusi awam dan swasta, dan kesalahan bahasa dalam kalangan pelajar, kajian kesalahan bahasa turut dilakukan terhadap dokumen-dokumen tertentu. Abdul Hamid Mahmood (2002) turut menyenaraikan faktor ketidakcekapan berbahasa Melayu baku dalam kalangan pelajar dengan bahan-bahan rujukan Bahasa Melayu. Dalam buku yang bertajuk "Guru dan Bahasa Melayu", Abdul Hamid Mahmood mengaitkan penggunaan Bahasa Melayu tidak baku dengan bahan rujukan seperti sesetengah buku teks yang mempunyai mutu bahasa yang belum cukup baik, bahan cetak dan media elektrik yang mempunyai mutu bahasa yang agak rendah.

Wong (2015) telah melakukan kajian tentang penggunaan Bahasa Melayu baku buku teks Geografi tingkatan satu. Kajian tersebut mengenal pasti kesalahan bahasa yang berlaku dalam buku teks tersebut berdasarkan rumus tatabahasa buku Tatabahasa Dewan Edisi Ketiga. Dapatan kajian beliau mendapati bahawa kesalahan ejaan, morfologi dan sintaksis berlaku dalam buku teks tersebut. Dalam kajian terhadap penggunaan Bahasa Melayu baku dalam soalan peperiksaan pula, kajian oleh Abdul Ghalib Yunus (2000) mendapati kertas soalan peperiksaan PMR dan SPM bagi tahun 1999 juga mempunyai kesalahan bahasa dari segi ejaan, kesalahan penggunaan kata struktur frasa kerja pasif, struktur frasa kerja transitif, struktur kerja tak transitif dan struktur ayat. Menurut Abdul Ghalib Yunus (2003), kekeliruan bahasa berlaku juga disebabkan oleh ketidaksepakatan dalam sesuatu hal yang berkaitan dengan tatabahasa. Kajian Abdul Ghalib Yunus diperkukuh oleh kajian Zaharani Ahmad (2007). Dalam kajian tersebut, Zaharani Ahmad menyatakan bahawa percanggahan bahasa antara nahu sekolah dengan nahu praktis akan menimbulkan kekeliruan dan mendatangkan permasalahan kepada masyarakat pengguna bahasa, khususnya para pelajar sekolah.

Sebagai rumusannya, melalui penelitian terhadap kajian-kajian yang berkaitan dengan penggunaan Bahasa Melayu baku khususnya dari aspek tatabahasa yang telah dikemukakan. dapat disimpulkan bahawa isu tentang penggunaan Bahasa Melayu baku sering dikaitkan dengan kesalahan 
bahasa. Kesalahan tersebut berlaku di mana-mana sahaja, iaitu bukan sahaja berlaku di institusi awam atau swasta, malah dokumen rasmi termasuklah kertas peperiksaan juga mempunyai kesalahan bahasa. Faktor-faktor yang dikenal pasti sebagai penyebab penggunaan Bahasa Melayu tidak baku hampir sama. Walau bagaimanapun, ada pengkaji lain mengemukakan pendapat bahawa penyebab penggunaan Bahasa Melayu secara tidak baku dalam kalangan pengguna bahasa disebabkan mutu bahasa bahan rujukan dan percanggahan pendapat dalam penghuraian sesuatu penggunaan bahasa.

\section{KAEDAH KAJIAN}

\section{Reka Bentuk Kajian}

Kajian ini merupakan kajian tinjauan deskriptif terhadap bahan-bahan kajian yang dipilih. Bahan-bahan yang terpilih dianalisis kandungannya bagi mengesan aspek yang ingin dikaji, iaitu percanggahan pendapat tentang sesuatu aspek yang diteliti dalam kajian ini. Menurut Sidek Mohd Noah (2002), kajian deskriptif dijalankan bertujuan untuk memberikan penerangan yang sistematik mengenai fakta dan ciriciri sesuatu populasi atau bidang yang diminati secara fakta dan tepat. Tinjauan melalui soal selidik terhadap 23 orang guru pula dilakukan bagi melihat kesan percanggahan pendapat terhadap mereka. Selain itu, kajian ini turut menggunakan kaedah kepustakaan dengan merujuk bahan-bahan bacaan termasuklah kajian terdahulu bagi mendapatkan fakta-fakta yang relevan bertujuan menggambarkan dan memperkukuh persoalan yang dibincangkan dalam kajian ini.

\section{Sample Kajian}

Kajian ini menggunakan persampelan bertujuan (purposive sampling) untuk mendedahkan fenomena yang ingin dikaji selaras dengan kajian ini sebagai kajian deskriptif. Menurut Othman Lebar (2006), persampelan bertujuan mendapatkan pemahaman tentang fenomena yang dikaji dengan cara teliti dan bertujuan. Begitu juga pendapat Rohana Yusof (2003) bahawa melalui persampelan bertujuan, data dipilih bagi menjawab persoalan kajian. Melalui penelitian terhadap bahan kajian, data-data yang menunjukkan percanggahan pendapat tentang sesuatu aspek tatabahasa yang menjadi fokus kajian ini dipilih. Sampel kajian turut melibatkan 23 orang guru sekolah bagi menjawab objektif (3) kajian ini. Mereka dipilih ketika menjadi peserta kursus kebahasaan. Para responden ini diberikan taklimat tentang tujuan dan cara-cara menjawab soal selidik yang diedarkan kepada mereka.

\section{Bahan Kajian}

Bahan kajian ini terdiri daripada bahan bercetak dan arkib soalan "Khidmat Bahasa" (dalam talian). Pemilihan bahan rujukan ini sebagai bahan kajian dibuat berdasarkan kedekatan dan kredibilitinya sebagai bahan rujukan kepada pengguna BM. Rasional pemilihan setiap satu bahan rujukan dijelaskan secara ringkas seperti berikut:

i. Buku Tatabahasa Dewan Edisi Ketiga (2014) \& Daftar Kata Bahasa Melayu Edisi Kedua (2008) Tatabahasa Dewan Edisi Ketiga, terbitan tahun 2014 (selepas ini disebut "TDE3") dan Daftar Kata Bahasa Melayu Edisi Kedua, terbitan tahun 2008 (selepas ini disebut "DKBME2") merupakan buku pegangan dalam pengajaran dan pembelajaran (PdP) (Bahagian Perkembangan Kurikulum, 2003). Menurut Nik Safiah Karim, Farid M. Onn, Hashim Musa \& Abdul Hamid Mahmood (2014), tatabahasa rujukan atau pegangan ialah suatu hasil yang dapat memberikan panduan dan menjadi asas rujukan penuturnya.

ii. Kamus Dewan Edisi Keempat (2015)

Kamus Dewan Edisi Keempat (selepas ini disebut "KDE4") merupakan sebuah kamus umum BM yang paling autentik yang menjadi rujukan utama pengguna BM di Malaysia dan para pengkaji bahasa di seluruh dunia (Kamus Dewan 2015: xv). 
iii. Majalah Pelita Bahasa (Terbitan April 2004)

Majalah Pelita Bahasa (selepas ini, singkatan "PB" merupakan bahan bacaan ringan yang dapat dijadikan sumber rujukan berhubung dengan soal-soal bahasa. Isinya bukan sahaja bersifat informatif, tetapi juga merupakan sumber rujukan dan pedoman dalam bidang bahasa yang berwibawa. Guru, pelajar menengah rendah dan tinggi, mahasiswa, kakitangan kerajaan dan pengguna bahasa yang lain sebagai pembaca sasaran [Dewan Bahasa \& Pustaka, t.t(a)].

iv. Koleksi Pedoman Bahasa DBP

Sebagai amalan penggunaan Bahasa Melayu yang baik dan berkesan sepanjang masa, pihak DBP telah mengambil inisiatif menerbitkan pedoman bahasa dan lain-lain khasnya untuk pelanggan DBP yang terdiri daripada guru, pelajar, kakitangan awam, karyawan dan individu [Dewan Bahasa \& Pustaka, t.t(c)]. Kajian ini memilih "Koleksi Pedoman Bahasa Bil.1" terbitan tahun 2006 sebagai bahan kajian.

v. Khidmat Nasihat DBP

Perkhidmatan yang disediakan bagi membantu pengguna menyelesaikan masalah dan kekeliruan yang berkaitan dengan kebahasaan, kesusasteraan, penerbitan, pengurusan dan khidmat korporat DBP. Pertanyaaan akan dijawab oleh Pegawai Khidmat Nasihat Bahasa dan Pakar Rujuk Bahasa [Dewan Bahasa \& Pustaka, t.t (b)]. Kajian ini telah memetik dua data daripada arkib soalan dalam Khidmat Bahasa untuk dianalisis. Dua data tersebut masingmasingnya dipetik daripada alamat internet (URL), iaitu http://sbmb.dbp.gov.my/kndbp/soalanlazim/nb soalan lazim.aspx (Data tentang pola ayat), dan http://sbmb.dbp.gov.my/kndbp/SoalJawab/nb rekod_pertanyaan.aspx (Data tentang ayat susunan songsang)

vi. Buku Teks Geografi Tingkatan 1: Kurikulum Bersepadu Sekolah Menengah

Melalui konsep Bahasa Melayu Merentas Kurikulum (BMMK) oleh Kementerian Pelajaran Malaysia pada tahun 1988, mata pelajaran lain yang menggunakan BM sebagai bahasa pengantar juga menjadi saluran penting bagi memastikan matlamat BMMK tercapai (Wong, 2015). Buku teks yang dijadikan bahan kajian ini buku ialah Geografi Tingkatan 1: Kurikulum Bersepadu Sekolah Menengah yang ditulis oleh Rape'ah Ahamed, Khalijah Maimon, Aziah Ismail, dan Foo, H. L. , terbitan pada tahun 2002 oleh Arus Intelek Sdn. Bhd, Kuala Lumpur.

\section{SKOP KAJIAN}

Kajian ini terbatas kepada beberapa bahan rujukan yang dipilih. Data-data kajian diperoleh secara tinjauan dan dipilih semata-mata untuk menjawab objektif kajian. Kajian ini juga hanya memfokuskan aspek tatabahasa bagi melihat percanggahan pendapat mengenainya. Bagi melihat kesan daripada percanggahan pendapat ini, kajian ini juga melakukan tinjauan terhadap 23 orang guru sekolah tentang penggunaan kata bantu dalam ayat.

\section{ANALISIS DATA}

Kajian kualitatif ini dijalankan melalui kaedah analisis kandungan. Menurut Rohana Yusof (2003), kaedah analisis kandungan yang dilakukan adalah dengan memetik maklumat yang diperlukan daripada arkib. Analisis kandungan juga boleh digunakan untuk kajian bersifat kualitatif bergantung pada objektif kajian yang dijalankan. Data kualitatif dianalisis dan dikategorikan mengikut cara yang disarankan oleh Ritchie dan Spencer (1994). Kajian ini membaca bahan kajian untuk mengutip data mengikut kategori yang diperlukan selaras dengan objektif kajian. Selepas itu, data ini dimurnikan atau disatukan kategori tersebut sebelum disemak semula. Bagi menggambarkan kesan percanggahan pendapat aspek tatabahasa terhadap pengguna bahasa (objektif 3), kajian ini menggunakan analisis statistik deskriptif. Menurut Rohana Yusof (2003) analisis statistik dekriptif digunakan untuk 
memerihalkan sesuatu peristiwa dan terhad kepada sampel sahaja serta tidak digunakan bagi membuat sesuatu kesimpulan ataupun generalisasi yang menyeluruh kepada populasi yang dikaji.

\section{DAPATAN DAN PERBINCANGAN}

\section{Objektif 1: Percanggahan Pendapat Aspek Tatabahasa dalam Bahan Rujukan itu Sendiri}

\section{Percanggahan Pendapat dalam TDE3}

1a. Percanggahan Huraian dengan Contoh tentang Susunan Ayat Songsang

Percanggahan berlaku dalam pemberian contoh kepada sesuatu huraian tentang susunan ayat songsang ini dapat dilihat dalam TDE3, muka surat 481. Percanggahan yang dimaksudkan ialah pemberian contoh bagi huraian "pendepanan kata kerja dengan objek" tidak tekal. Perhatikan ayat 218(b), 220 (b) dan 222(b) pada muka surat 481 dalam buku TDE3 seperti yang berikut:

218. a. Dia membaca buku di perpustakaan.

218. b. Membaca buku dia di perpustakaan.

220. a. Ali tersepak batu dalam permainan itu.

220. b. Tersepak batu Ali dalam permainan itu.

222. a. Murid nakal itu kena rotan kelmarin.

222. b. *Kena rotan murid nakal itu kelmarin.

Contoh ayat songsang ayat 218(b), 220 (b) dan 222(b) adalah tidak tekal tentang "pendepanan kata kerja dengan objek". Bagi menjelaskan pendepanan kata kerja dengan objek, ayat 218(b) dan 220(b) adalah tepat. Walau bagaimanapun, ayat songsang 222(b), tidak jelas menunjukkan pendepanan yang dimaksudkan kerana tidak berlaku pendepanan objek. Menurut Nik Safiah Karim et al. (2014:493), dalam ayat pasif dengan kata bantu pasif "kena", ayat pasif jenis ini mengandungi perkataan "kena" di hadapan kata kerja dasar yang tidak menerima awalan. Menurut Abdul Hamid Mahmood (1992:366), pasif "kena" boleh bertukar ganti dengan pasif "di" dan "ter" dari segi struktur. Dengan berdasarkan pendapat Nik Safiah Karim et al. (2014) dan Abdul Hamid Mahmood (1992), ayat aktif kepada ayat pasif 222(a) ialah "X merotan murid nakal itu", huruf " $x$ " diberikan sebagai merujuk "pelaku" dan subjek dalam ayat aktif". Andaikan "x" ialah "guru disiplin". Ayat aktif boleh dikatakan sebagai "Guru disiplin merotan murid nakal itu kelmarin". Ayat ini boleh dipasifkan menjadi "murid nakal itu dirotan oleh guru disiplin kelmarin" atau "murid nakal itu kena rotan oleh guru disiplin kelmarin". Melalui transformasi ayat, ayat "murid itu kena rotan oleh guru disiplin kelmarin" oleh digugurkan frasa sendi nama "oleh + frasa nama" sehingga menghasilkan ayat "murid itu kena rotan kelmarin" [seperti ayat 222(a)]. Ayat 222 (a) terdiri daripada subjek "murid nakal itu" dan predikat "kena rotan kelmarin". Untuk menghasilkan ayat 222 (b), pendepanan frasa "kena rotan" sahaja telah dilakukan dalam TDE3. Hal ini tidak menampakkan "objek", iaitu "murid nakal itu" yang ketika itu menjadi subjek dalam ragam ayat pasif "dikedepankan". Sebaliknya ayat 218(b) \& 220(b) menunjukkan contoh yang jelas tentang hasil pendepanan kata kerja objek.

1b. Percanggahan tentang Penggunaan Kata Kerja Terbitan "Diperbuat" dengan "Dibuat"

Penghuraian tentang kata kerja "diperbuat" dan "dibuat" juga menampakkan percanggahan pendapat berlaku dalam TDE3. Perhatikan rujuk silang yang telah dilakukan oleh kajian ini tentang beberapa pernyataan yang terdapat dalam TDE3 (muka surat 178, 181, 182 dan 426): 
Pernyataan 1: Penggunaan "memper-" dengan kata kerja, iaitu "memperbuat" merupakan bentuk lewah bagi "membuat" (TDE3, muka surat 178)

Pernyataan 2: Awalan "diper-" dapat bergabung dengan kata dasar yang terdiri daripada kata nama, kata adjektif dan kata tugas. (TDE3, muka surat 181)

Pernyataan 3: Sebagaimana yang berlaku pada awalan "memper-", awalan "diper-" juga boleh bergabung dengan kata kerja "buat" menjadi "diperbuat". Bentuk ini juga dianggap lewah bagi "dibuat". (TDE3, muka surat 182)

Ayat $\quad$ : Kerusi itu diperbuat daripada kayu dan daripada rotan. (Ayat 45, TDE3, muka surat 426)

Dengan berdasarkan pernyataan dan contoh ayat di atas, "pernyataan 1" menunjukkan "memperbuat" bersifat lewah. "Pernyataan 2" pula menjelaskan bahawa awalan "diper-" dapat bergabung dengan kata dasar yang terdiri daripada kata nama, kata adjektif dan kata tugas. Tidak dinyatakan "diper-" dapat bergabung dengan kata dasar kerja. Melalui penyenaraian sedemikian, kajian ini menyimpulkan "diper-" tidak dapat bergabung dengan kata dasar kata kerja atas alasan penggabungan dengan kata kerja tidak disenaraikan di sini. "Pernyataan 3" pula menunjukkan "diperbuat" sebagai bersifat lewah kerana penggunaan "sebagaimana berlaku pada awalan "memper-" (dalam pernyataan 1, ada dinyatakan "memperbuat" dianggap lewah). Hal ini diperkukuh dengan huraian yang wujud selepasnya dalam pernyataan 3, iaitu "diperbuat" dianggap lewah bagi "dibuat". Walau bagaimanapun, dalam penulisan selepas itu, penggunaan "diperbuat" muncul kembali dengan ayat "kerusi itu diperbuat daripada kayu dan daripada rotan" (ayat 45, TDE3, muka surat 426). Hal ini telah menampakkan percanggahan pendapat melalui contoh ayat dengan pernyataan yang diberikan sebelum itu.

\section{Percanggahan Pendapat dalam "Koleksi Pedoman Bahasa Bil.1", Terbitan tahun 2006.}

2a. Percanggahan tentang Penggunaan Kata Pemeri

Dalam Koleksi Pedoman Bahasa Bil.1, dijelaskan penggunaan kata pemeri "ialah" dan "adalah", yakni kata pemeri "ialah" menunjukkan persamaan dan hadir di hadapan frasa nama, manakala "adalah" yang menunjukkan huraian dan hadir di hadapan frasa adjektif dan frasa sendi nama (Bahagian Pengembangan Bahasa Melayu, 2006:10). Antara contoh penggunaan kata pemeri dalam ayat yang ditunjukkan dalam buku tersebut ialah:

Kursus ini adalah untuk... (muka surat 11)

Masakan anda lupa akan tulisan anda sendiri yang mencatatkan bahawa awalan "me" adalah antara pembentuk kata kerja yang penting (muka surat 21)

Contoh penggunaan kata pemeri "adalah" dalam kedua-dua ayat di atas dijelaskan dalam buku tersebut sebagai "menunjukkan huraian dan hadir di hadapan frasa sendi nama". Walau bagaimanapun, kajian ini mendapati bahawa penggunaan kata pemeri di hadapan kata sendi nama/ frasa sendi nama yang disebutkan sebelum ini tidak tekal kerana wujud percanggahan dalam contoh ayat yang diberikan dalam buku yang sama. Ketidakselarasan yang dimaksudkan adalah seperti ayat berikut:

Di Australia, Bahasa Melayu ialah antara mata pelajaran yang paling digemari penuntut. (muka surat 20)

Dalam ayat tersebut, kajian ini berpendapat bahawa penggunaan kata pemeri "ialah" seharusnya digantikan dengan "adalah" seperti yang dijelaskan dalam buku tersebut sebelum itu.

\section{Percanggahan dalam "Khidmat Nasihat DBP" Secara dalam Talian}

Percanggahan pendapat dalam "Khidmat Nasihat DBP" secara dalam talian dapat dilihat melalui soal jawab dalam "situasi 1" dan "situasi 2" seperti berikut: 
3a. Situasi 1: Percanggahan Pendapat tentang Susunan Ayat.

Pertanyaan : Yang manakah betul antara ayat berikut? "Antara pernyataan yang berikut, manakah pernyataan yang betul tentang maksud fotosintesis?" ATAU "Antara berikut, yang manakah betul tentang maksud fotosintesis?" ATAU Yang manakah betul antara berikut tentang maksud fotosintesis?" Terima kasih.

Khidmat Nasihat : Ayat yang gramatis ialah "Antara berikut, yang manakah DBP betul tentang maksud fotosintesis?"

Pertanyaan $\quad: \quad$ Bagaimanakah susunan biasa bagi ayat songsang tersebut?

Khidmat Nasihat : Ayat tanya tiada susunan songsang.

DBP

Pertanyaan : Dengan berdasarkan jawapan yang tuan berikan bahawa "ayat tanya tiada dalam susunan songsang", boleh tak tuan meneliti pernyataan tersebut kerana pernyataan tersebut tidak sama dengan pernyataan Tatabahasa Dewan Edisi Ketiga (m.s.444) yang menyatakan bahawa ayat tanya "Encik Alikah guru itu?"; "Orang muda itukah pengurusnya?" merupakan ayat songsang hasil daripada pendepanan predikat. Harap mendapat penjelasan yang lebih mendalam.

Khidmat Nasihat : Kami mohon maaf atas kekeliruan tersebut. Ayat tanya DBP boleh hadir dalam susunan songsang hasil pendepanan predikat, seperti ayat contoh yang tuan berikan.

Melalui situasi 1 di atas, didapati bahawa jawapan yang diberikan dalam Khidmat Nasihat adalah tidak tekal tentang ayat tanya susunan songsang. Pada awalnya, dikatakan "ayat tanya tiada susunan songsang" tetapi kemudiannya "ayat tanya boleh hadir dalam susunan songsang hasil pendepanan predikat".

3b. Situasi 2: Percanggahan Pendapat tentang Pola Ayat Dasar

$\begin{array}{lll}\text { Pertanyaan } & \text { Apakah pola ayat "Bandar raya Kuching terletak di } \\ & \text { Sarawak"? } \\ \begin{array}{l}\text { Khidmat Nasihat } \\ \text { DBP }\end{array} & \text { Ayat penyata (FN+FN) } \\ \text { Pertanyaan } & : \quad \begin{array}{l}\text { Tuan, saya masih kurang pasti dengan jawapan bahawa pola } \\ \text { ayat "Bandar raya Kuching terletak di Sarawak" ialah }\end{array} \\ & \begin{array}{l}\text { FN+FN. Bukankah frasa "terletak di Sarawak" ialah } \\ \text { frasa kerja (FK)? }\end{array}\end{array}$

Khidmat Nasihat : Pola ayat tersebut memang pola FN+FK kerana kata DBP "terletak" ialah kata kerja. Maaf atas kesilapan yang diberikan oleh petugas sebelum ini. 
Melalui situasi 2 di atas, didapati bahawa jawapan yang diberikan dalam Khidmat Nasihat juga adalah tidak tekal tentang pola ayat dasar. Pada awalnya, dikatakan bahawa pola ayat dasar "Bandar raya Kuching terletak di Sarawak" ialah "frasa nama + frasa nama" tetapi kemudiannya menyatakan ayat tersebut merupakan pola "frasa nama + frasa kerja".

\section{Objektif 2: Percanggahan Pendapat Aspek Tatabahasa Antara Bahan Rujukan}

\section{Percanggahan Pendapat antara TDE3 dengan Koleksi Pedoman Bahasa Bil. 1} nama berikut:

Percanggahan pendapat yang dimaksudkan adalah tentang frasa keterangan daripada frasa sendi

Antara kain-kain merah itu, kain jenis sutera itulah yang termerah (Ayat 135, TDE3, muka surat 236)

Terdapat sebilangan kata dalam BM seperti "antara", "barisan", "daftar", "deretan", "gabungan", "gugusan", "jemaah", "mesyuarat", "pelbagai", "perhimpunan" dan "senarai" yang bermakna "kumpulan" atau "banyak", iaitu yang melibatkan orang, benda, unsur, perkara dan sebagainya yang lebih daripada satu. Oleh itu, kita tidak perlu menggandakan perkataan yang mengikutnya. Sebagai contoh "Antara maklumat-maklumat..." sepatutnya ditulis sebagai "antara maklumat...."; "antara lagu-lagu...." Sepatutnya "Antara lagu...." (Bahagian Pengembangan Bahasa Melayu, 2006). Jadi, jika dibandingkan contoh ayat (135) dalam TDE3 di atas dengan penjelasan yang diberikan oleh Pedoman Bahasa, ternyata berlaku percanggahan pendapat.

\section{Percanggahan pendapat antara Buku Teks dengan TDE3 dan DKBME2}

Dalam satu kajian tinjauan tentang penggunaan BM dalam buku teks Geografi Tingkatan Satu", Wong (2015) telah melakukan penelitian aspek ejaan dan tatabahasa dalam buku tersebut berdasarkan TDE3 dan DKBM sebagai rujukan utama. Antara ketidakselarasan atau percanggahan penggunaan BM dalam buku teks tersebut dengan TDE3 dan DKBME2 adalah seperti berikut:

Ketidakselarasan

Mengeja kata Terbitan secara terpisah

Kata Pemeri

Kata Sendi Nama "di"

Frasa Sendi Nama "Oleh kerana"

Frasa Kerja Transitif
Contoh dalam Buku Teks (muka surat)

Juru ukur (m.s.18), sosio-ekonomi (m.s. 115), eko pelancongan (m.s.161)

Langkah ini ialah untuk memastikan hasil hutan dapat dikekalkan (m.s.174)

... untuk menghalang kehilangan air akibat perpeluhan di musim panas dan kering (m.s.151)

Oleh kerana bumi berbentuk sfera dan berputar dari barat ke timur, maka... (m.s 85)

Anda telah mempelajari tentang ciri-ciri cuaca dan iklim di negara kita (m.s.116)

\section{Percanggahan Kamus Dewan dengan TDE3 dan Koleksi Pedoman Bahasa Bil.1}

Menurut Zaharani Ahmad (2008), secara prinsipnya, korpus, rumus, dan kamus haruslah selari dan tidak bercanggah antara satu sama lain kerana ketiga-tiganya dipetik daripada satu sumber yang sama, iaitu bahasa yang digunakan oleh penuturnya. Namun begitu, ada kalanya data daripada korpus didapati 
bercanggah dengan rumus yang sedia ada, dan ini mendatangkan persoalan dan permasalahan dalam penyusunan kamus.

\section{3a. Percanggahan Pendapat tentang Makna Apitan beR-...-an}

Percanggahan pendapat tentang makna apitan "beR-...-an" dapat dilihat berdasarkan dua ayat berikut:

Ayat 1: $\quad$ Ia memerhatikan gambar-gambar yang bergantungan di dinding (Kamus Dewan, 2015:433).

Ayat 2: $\quad$ Lampu merah bergantungan di dinding (TDE3 \& Koleksi Pedoman Bahasa Bil.1).

Menurut Nik Safiah Karim et al (2014), penggunaan apitan beR-...-an menghasilkan bentuk kata kerja terbitan yang membawa maksud perbuatan yang menunjukkan jumlah subjek yang banyak. Dalam Koleksi Pedoman Bahasa (Bahagian Pengembangan Bahasa Melayu, 2006), kata kerja berimbuhan apitan "ber-...-an" seperti "bergantungan", "bertaburan" dan sebagainya membawa maksud perbuatan yang menunjukkan jumlah yang banyak atau berulang-ulang dengan banyaknya. Oleh itu kata nama yang hadir sebelumnya tidak perlu digandakan lagi. Pernyataan ini bercanggah dengan contoh ayat daripada Kamus Dewan (2015).

\section{3b. Percanggahan Frasa Kerja yang Melibatkan Kata Kerja "Memberi”}

Penggunaan perkataan "memberi" bukan sahaja tidak tekal dalam KD sendiri, malah bercanggah dengan TDE3. Kamus Dewan (2015) memberikan contoh frasa kerja "memberi pertolongan" tetapi menulisnya sebagai "memberikan pertolongan" pada muka surat 170. Jika dirujuk pada TDE3 pula, kata dasar "beri" apabila menerima apitan meN-...-kan lazimnya menerima objek yang tidak bernyawa dan apitan meN-...-I menerima objek yang bernyawa seperti "Ali memberi kucing makanan" dan "Ali memberikan makanan kepada kucing” (Nik Safiah Karim et al., 2014).

\section{Percanggahan Pendapat antara Penulis Nahu Bahasa tentang Kata Bantu "Boleh" dan "Dapat"}

Percanggahan pendapat berlaku tentang penggunaan kata bantu "boleh" dan "dapat". Menurut Asmah Haji Omar (1982), Kata kerja modalitas "boleh" mempunyai komponen makna keupayaan dan keizinan seperti ayat berikut:

a. "Boleh" membawa makna "keupayaan"

- Anak saya sudah boleh berjalan.

- Dia boleh bercakap dalam tiga bahasa.

b. "Boleh" membawa makna "keizinan"

- Loceng sudah berbunyi. Kita boleh keluar.

- Kita tidak boleh berniat jahat

- Dia tidak boleh naik darjah, kerana tidak lulus peperiksaan kelayakan.

Menurut Asmah Haji Omar lagi, kata kerja Modalitas "dapat" pula hanya mempunyai komponen makna keupayaan dan "dapat" hanya boleh menggantikan "boleh" untuk membawa makna "keupayaan seperti ayat berikut:

- Kakinya masih sakit. Dapatkah dia berjalan?

- Hari itu hujan. Saya tidak dapat hadir di mesyuarat itu.

Penggunaan kata kerja modalitas "boleh" ini disamakan dengan dengan kata kerja modalitas "bisa" yang dipinjam daripada bahasa Jawa melalui bahasa Indonesia, yakni boleh dipakai dengan makna "keupayaan" dan juga "keizinan". 
Nik Safiah Karim et al. (2014) pula menjeniskan perkataan "boleh" dan "dapat" sebagai kata bantu ragam. Kata bantu ragam ialah bentuk kata yang menyatakan atau menerangkan ragam perasaan yang berkaitan dengan perbuatan yang dilakukan. Dalam TDE3, tidak dijelaskan tentang perbezaan penggunaan "boleh" dan "dapat" ini dari segi "kemampuan" atau "keizinan". Walau bagaimanapun, dapat dikesan bahawa terdapat beberapa ayat yang mengandungi kata bantu "boleh" dalam buku TDE3, iaitu:

- Kita boleh ke Johor Bahru dengan bas.

- Kami dapat pulang ke kampung pada masa cuti persekolahan.

- Bersukan dan bersenam boleh menyihatkan badan

Dengan berdasarkan ayat, "bersukan dan bersenam boleh menyihatkan badan" di atas, penggunaan "boleh" didapati membawa maksud "keupayaan atau kemampuan" kerana ayat tersebut dapat disebut sebagai "bersukan dan bersenam (mampu/berupaya/dapat) menyihatkan badan. Sebaliknya, jika penggunaan "boleh" hanya membawa makna "keizinan", maka ayat tersebut mempunyai kesalahan bahasa kerana adalah tidak sesuai jika dikatakan bahawa "bersukan" diizinkan atau mendapat izin "menyihatkan badan". Penggunaan "boleh" dalam ayat tersebut menunjukkan bahawa "boleh" juga membawa maksud "mampu". Hal ini selaras dengan definisi yang diberikan Asmah Omar (1982). KD (2015) \& Kamus Pelajar Edisi Kedua (2009) yang turut menjelaskan "boleh" sebagai membawa makna "dapat" dan "mampu" selain bermaksud "dibenarkan" atau "diizinkan".

Pernyataan daripada Khidmat Nasihat DBP [http://prpmv1.dbp.gov.my/Search. aspx?k=diizinkan\&d=10] pula berbeza sedikit dengan pendapat Nahu Melayu Muktahir, TDE3, Kamus Dewan dan Kamus Pelajar Edisi kedua kerana Khidmat bahasa DBP menyatakan "boleh" dan "dapat" mempunyai makna yang sama, iaitu mampu (berkeupayaan), tidak disekat atau dihalang daripada berbuat atau melakukan sesuatu, dibenarkan, diizinkan tetapi buku-buku tersebut tidak menyatakan "dapat" membawa maksud "keizinan".

Terdapat juga pihak lain yang mempunyai pandangan yang berbeza. Abdul Ghalib Yunus (2000) menyatakan bahawa "boleh" lebih tepat digunakan dalam hubungan dengan "keizinan". Kata "dapat" pula lebih sesuai digunakan dalam hubungan dengan "keupayaan atau kemampuan". PB (2004) juga mempunyai pendapat yang sama dengan Abdul Ghalib Yunus bahawa ada perbezaan antara keduadua perkataan tersebut ('boleh' dan 'dapat'). Kata bantu "boleh" mempunyai maksud "tidak dilarang untuk melakukan sesuatu" atau "diberi izin untuk melakukan sesuatu". Kata bantu "dapat" bermaksud "berupaya melakukan sesuatu".

Menurut Awang Sariyan (2005) pula, kata "boleh" dan "dapat" sebenarnya pada asalnya mempunyai makna yang berbeza. Kata "boleh" lebih sesuai digunakan dalam hubungannya dengan "keizinan". Kata "dapat" pula lebih sesuai digunakan dalam hubungannya dengan "keupayaan atau kemampuan". Menurut Awang Sariyan (2006), penggunaan kata "boleh" dalam ayat di bawah berlaku dalam konteks yang salah kerana "boleh" bererti diizinkan. Kata yang tepat ialah "dapat". Perhatikan contoh kesalahan penggunaan "boleh" dalam ayat di bawah:

- "Seperti yang boleh dilihat, borang JPM "E” hendaklah juga digunakan..."

Menurut Awang Sariyan lagi, dalam perkembangannya, kini kata "dapat" dan "boleh" dapat dianggap bersinonim dalam konteks tertentu. Misalnya, ungkapan "Malaysia Boleh" menunjukkan makna keupayaan. Walau bagaimanapun, makna asal kedua-dua kata itu kekal dan sebaik-baiknya gunakanlah dengan tepat (Awang Sariyan, 2005). Dengan berdasarkan pernyataan Awang Sariyan (2005, 2006), jelas menunjukkan bahawa beliau memberikan pengelasan makna yang jelas antara "boleh" dengan "dapat", iaitu "boleh" berkaitan dengan "keizinan" manakala "dapat" bermaksud "berkeupayaan". Walau bagaimanapun pernyataan beliau selepas itu juga menampakkan bahawa beliau tidak menafikan "boleh" juga membawa makna "keupayaan" dalam konteks tertentu.

Dengan berdasarkan pandangan-pandangan yang dikemukakan berhubung dengan penggunaan kata bantu "boleh", maka satu rumusan dapat dibuat seperti dalam Jadual 1 di bawah: 
JADUAL 1 Pandangan tentang Penggunaan Kata Bantu "Boleh"

\begin{tabular}{|c|c|c|c|c|c|c|c|c|}
\hline $\begin{array}{l}\text { Makna kata bantu } \\
\text { "Boleh": }\end{array}$ & 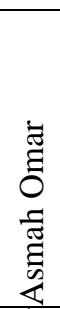 & 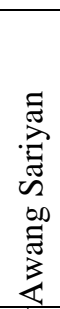 & 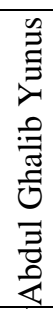 & 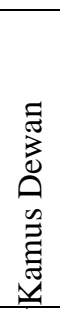 & 茼 & 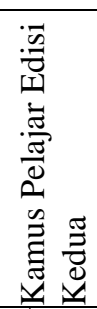 & 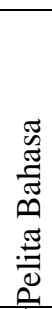 & 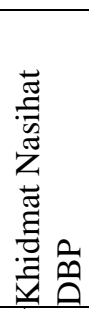 \\
\hline (i) Keizinan & $\sqrt{ }$ & $\sqrt{ }$ & $\sqrt{ }$ & $\sqrt{ }$ & $\sqrt[3]{ }$ & $\sqrt{ }$ & $\sqrt{ }$ & $\sqrt{ }$ \\
\hline (ii) Kemampuan & $\sqrt{ }$ & & & & $\sqrt{ }$ & $\sqrt{ }$ & & $\sqrt{ }$ \\
\hline
\end{tabular}

Dengan berdasarkan Jadual 1, dapat dilihat bahawa terdapat pelbagai pandangan tentang penggunaan kata bantu "boleh". Ada pendapat yang menyatakan kata bantu "boleh" membawa keduadua maksud, iaitu "keizinan" dan "kemampuan", manakala ada yang menyatakan bahawa "boleh" hanya berkaitan dengan "keizinan", tidak kurang juga ada yang menunjukkan pendirian yang tidak jelas, iaitu "asalnya berbeza" tetapi bergantung pada konteks penggunaannya.

\section{Objektif 3: Kesan-Kesan Percanggahan Pendapat Aspek Tatabahasa Kepada Pengguna Bahasa}

Seandainya mengikut pendapat bahawa kata bantu "boleh" bermaksud "keizinan" dan "dapat" bermaksud "kemampuan", maka pengguna bahasa akan keliru tentang penggunaan kata bantu secara tepat. Hal ini dibuktikan melalui dapatan tinjauan terhadap 23 orang responden yang terdiri daripada guru-guru di sebuah sekolah tentang penggunaan "boleh" dan "dapat" dalam soalan isi tempat kosong seperti yang berikut:

Adik saya baru berumur lima belas tahun, tetapi sudah (1) memandu kereta. Namun demikian, ia belum (2) memandu kereta di jalan raya oleh sebab lesen memandu hanya (3) diberikan kepada orang yang berumur sekurangkurangnya lapan belas tahun.

Dengan berdasarkan soalan isi tempat kosong yang dikemukakan kepada responden di atas, dapat ditunjukkan bahawa $65 \%$ responden memilih "boleh" sebagai jawapan, manakala $35 \%$ responden memilih "dapat" bagi item 1 . Hal ini menunjukkan bahawa $65 \%$ beranggapan bahawa "boleh" juga dapat membawa maksud "dapat". Bagi Item kedua, sebanyak 47.8\% memilih "boleh", manakala 52\% memilih "dapat". Hal ini bermakna, responden tersebut juga beranggapan "boleh" dapat digantikan dengan "dapat". Begitu juga item ketiga, sebanyak $21.7 \%$ responden memilih "dapat" sebagai menggantikan jawapan "boleh" manakala sebanyak 78\% memilih "boleh" sebagai jawapan yang sepatutnya jika mengikut beberapa pendapat yang dikemukakan.

\section{IMPLIKASI KAJIAN}

Secara keseluruhannya, kajian ini telah menghasilkan maklumat-maklumat penting tentang percanggahan pendapat tatabahasa dalam bahan rujukan Bahasa Melayu. Maklumat ini diharapkan dapat dimanfaatkan oleh pelbagai pihak dalam usaha memastikan penggunaan Bahasa Melayu baku yang lebih mantap dalam kalangan pengguna Bahasa Melayu.

Sesungguhnya, buku TDE3 itu sendiri masih mempunyai maklumat yang bercanggah. Sebagai buku pegangan, buku ini haruslah bersifat tekal dan tidak bercanggah dalam sesuatu huraian aspek tatabahasa. Hal ini akan memastikan tahap keyakinan pengguna bahasa terhadap buku pegangan ini berkekalan. Selain itu, buku teks mata pelajaran lain selain buku teks Bahasa Melayu juga mengandungi kesalahan bahasa dan tidak selaras dengan rumus tatabahasa dalam buku TDE3. Bahan bacaan yang 
penting bagi pelajar ini tentu akan mempengaruhi pelajar ke arah penggunaan bahasa yang tidak baku. Seharusnya, pihak yang menerbitkan buku teks harus meneliti rumus tatabahasa dalam buku Tatabahasa Dewan Edisi Ketiga seoptimum mungkin agar kesalahan bahasa dapat dikurangkan pada tahap yang paling minimum dalam buku teks. Hal ini kerana bahan rujukan ini menjadi bahan bacaan yang penting kepada pelajar. Penyemakan yang teliti perlu dilakukan bagi memastikan mutu bahasa yang lebih sempurna tanpa kesilapan.

Dapatan kajian ini sesungguhnya dapat menyedarkan pelbagai pihak tentang percanggahan pendapat yang sering dilakukan ketika memberikan ulasan tentang penggunaan sesuatu bahasa secara baku. Bahan rujukan yang dimaksudkan ialah Kamus Dewan, Pelita Bahasa, Koleksi Pedoman Bahasa, dan Khidmat Nasihat DBP secara dalam Dalam Talian. Pihak tersebut haruslah memastikan maklumat bahasa yang disampaikan kepada pengguna bahasa selaras dengan rumus tatabahasa Tatabahasa Dewan kerana penerbitan dan khidmat yang diberikan ini merupakan usaha ke arah penggunaan Bahasa Melayu baku dalam kalangan pengguna bahasa.

Sesungguhnya, untuk mengelakkan percanggahan pendapat tentang aspek tatabahasa dalam bahan rujukan bukanlah mudah. Hal ini kerana terdapat pelbagai pendekatan dalam penghuraian sesuatu bahasa dan masing-masing mempunyai perspektif yang berbeza, iaitu pendekatan preskriptif dan deskriptif. Walau bagaimanapun, satu persetujuan bersama harus dicapai sesuai dengan sifat bahasa sebagai bersifat konvensional. Sekiranya percanggahan pendapat tentang tatabahasa dibiarkan berterusan, maka usaha pemupukan penggunaan Bahasa Melayu baku tentu akan terjejas kerana percanggahan akan mengelirukan pengguna bahasa malah penggunaan Bahasa Melayu secara tidak baku akan berleluasa.

\section{RUMUSAN}

Istilah Bahasa Melayu baku mempunyai skop yang luas, iaitu meliputi aspek ejaan, peristilahan, kosa kata, tatabahasa, sebutan dan laras bahasa. Dalam aspek tatabahasa, buku TDE3 merupakan bahan rujukan utama yang berwibawa dan menjadi buku pegangan kepada semua pengguna bahasa. Hal ini telah diperakukan oleh Kementerian Pendidikan Malaysia. Selain itu, KPM turut memperakukan buku "DKBME2" sebagai buku pegangan khususnya dalam usaha membakukan istilah dan ejaan. Kamus Dewan Edisi Keempat pula menjadi rujukan utama pengguna BM di Malaysia.

Selain tiga buah buku rujukan yang penting tersebut, DBP turut menyediakan pelbagai perkhidmatan sama ada berbentuk bahan bercetak ataupun secara dalam talian selaras dengan penubuhan institusi bahasa tersebut. Antaranya termasuklah penerbitan berkala seperti majalah "Pelita Bahasa", risalah "Koleksi Pedoman Bahasa" dan "Khidmat Nasihat DBP" secara dalam talian. Perkhidmatan tambahan ini merupakan usaha DBP bagi memastikan penggunaan Bahasa Melayu baku dalam pengguna bahasa. Hal ini bermakna, maklumat daripada perkhidmatan tambahan ini juga mestilah tepat dan boleh diyakini. Yang lebih penting maklumat tersebut selaras dengan Tatabahasa Dewan Edisi Ketiga.

Melalui konsep Bahasa Melayu Merentas Kurikulum (BMM) ternyata bahawa buku teks juga perlu menggunakan bahasa yang berkualiti, yakni Bahasa Melayu yang betul. Oleh itu, Bahasa Melayu dalam buku teks harus dikawal mutunya. Jurang pendapat antara pendekatan deskriptif dan preskriptif dalam penghuraian bahasa sering mengundang pelbagai pendapat dan keputusan mengenai penggunaan secara tepat sesuatu bahasa. Oleh itu, persepakatan antara linguis yang mempunyai aliran yang berbeza ini harus dirapatkan. Jika tidak, pengguna masih semakin keliru dan sukar menentukan peraturan bahasa yang sepatutnys perlu dipatuhi. Akhirnya, usaha pemartabatan Bahasa Melayu di negara ini turut terjejas. 


\section{RUJUKAN}

Abdul Ghalib Yunus. (2000). Kesalahan bahasa dalam soalan peperiksaan. Jurnal Dewan Bahasa. 44(4), 468483. Kuala Lumpur: Dewan Bahasa dan Pustaka.

Abdul Ghalib Yunus. (2003). Hingga dan ke. Pelita Bahasa Julai 2003. Kuala Lumpur: Dewan Bahasa dan Pustaka.

Abdul Hamid Mahmood. (1992). Ayat pasif bahasa Melayu. Kuala Lumpur: Dewan Bahasa dan Pustaka.

Ahmad Hamid Mahmood. (2002). Guru dan bahasa Melayu. Kuala Lumpur: Media Printext(M) Sdn. Bhd.

Asmah Omar. (1982). Nahu Melayu muktahir Kuala Lumpur: Dewan Bahasa dan Pustaka.

Awang Sariyan. (2005). Tuntunan bahasa asas pegangan Pelajar: Edisi Kedua. Petaling Jaya: Pearson Malaysia Sdn. Bhd.

Awang Sariyan (2006). Warna dan suasana perancangan bahasa Melayu di Malaysia: Edisi Kedua. Kuala Lumpur: Dewan Bahasa dan Pustaka.

Bahagian Pengembangan Bahasa Melayu. (2006). Koleksi pedoman bahasa Bil.1. Kuala Lumpur: Dewan Bahasa dan Pustaka.

Corder, S.P. 1981. Error analysis and interlanguage. London: Oxford University Press.

Chew, F. P. (2008). Budaya dan masyarakat berbilang kaum di Malaysia. Kuala Lumpur: Kementerian Perpaduan Kebudayaan, Kesenian dan Warisan Malaysia.

Dewan Bahasa \& Pustaka (t.t.a). Matlamat penerbitan majalah DBP. Dicapai pada 3 Januari 2018, daripada http://lamanweb.dbp.gov.my/index.php/pages/view/234.

Dewan Bahasa \& Pustaka (t.t.b). Khidmat Nasihat DBP. Dicapai pada 3 Januari 2018, daripada http://lamanweb.dbp.gov.my/index.php/pages/view/524.

Dewan Bahasa \& Pustaka, t.t(c). Pedoman dan Panduan Bahasa Melayu. Dicapai pada 3 Januari 2018 daripada http://lamanweb.dbp.gov.my/index.php/pages/view/72.

Daftar Kata Bahasa Melayu (2008) Edisi kedua. Kuala Lumpur: Dewan Bahasa dan Pustaka.

Junaini Kasdan, Nor Suhaila Che Pa \& Mohd Syamril Aklmar Che Kassim (2015). Penguasaan Bahasa Melayu Penjawat Awam: Kajian Kes di Universiti Teknikal Malaysia (MTUN). Jurnal Linguistik. 19(2), (45-61). Dicapai pada 25 September 2018, daripada https://www.researchgate.net /publication/301730664.

Kamus Dewan Edisi Keempat (2015). Kuala Lumpur: Dewan Bahasa dan Pustaka.

Kamus Pelajar Bahasa Malaysia Edisi Kedua (2009). Kuala Lumpur: Dewan Bahasa dan Pustaka.

Khidmat Nasihat DBP "boleh" dan "dapat". Dicapai pada 3 Januari 2018, daripada http://prpmv1.dbp.gov.my/Search. aspx?k=diizinkan\&d=10.

Liew, S.L., Yahya Othman \& Abdul Rasid Jamian (2003). Kesalahan bahasa dalam Karangan Pelajar Cina sekolah menengah. Jurnal Bahasa, 3(2), 206-225.

Mohammed Zin Nordin, Mohd Taib Ariffin, Khairul Azam Bahari \& Siti Munirah Md. Zukhi (2013). Analisis kesalahan pengunaan bahasa papan tanda perniagaan. Procedia - Social and Behavioral Sciences 134 (2014) $330-349$.

Othman Lebar (2006). Penyelidikan kualitatif: Pengenalan kepada teori dan metod. Tanjung Malim: Universiti Pendidikan Sultan Idris.

Nik Safiah Karim, Farid M. Onn, Hashim Musa \& Abdul Hamid Mahmood (2014). Tatabahasa dewan: Edisi Ketiga. Kuala Lumpur: Dewan Bahasa dan Pustaka.

Nur Syafiah Mohd Isa, (2014) Penguasaan Bahasa Melayu sebagai bahasa kedua dalam kalangan pelajar etnik Cina di sekolah menengah persendirian cina: satu kajian kes. Masters thesis, Universiti Malaysia Sabah. Dicapai pada 3 Januari 2018, daripada http://eprints.ums.edu.my/17627/.

Pelita bahasa (2004). Kuala Lumpur: Dewan Bahasa Pustaka.

Ritchie, J., \& Spencer, L (1994). Qualitative data analysis for applied policy research. In A. Bryman \& R. Burgess (Eds.). Analyzing Qualitative Data. London: Routledge.

Rohana Yusof. (2003). Penyelidikan sains sosial. Bentong: PTS Publications \& Distributors Sdn. Bhd.

Salinah Jaafar \& Rohaidah Haron (2016). Kesilapan bahasa Melayu dalam kalangan pelajar-pelajar Universiti Kebangsaan Yunnan di Akademi Pengajian Melayu. Jurnal Melayu. 15(2), 196-209.

Sidek Mohd. Noah. (2002). Reka bentuk penyelidikan: Falsafah, teori dan praktis. Serdang: Universiti Putra Malaysia.

Siti Baidura Kasiran (2011). Analisis Kesalahan Tatabahasa Bahasa Melayu dalam Karangan Pelajar Asing di Sebuah Institusi Pengajian Tinggi Awam. Dicapai pada 3 Januari 2018, daripada http://irep.iium.edu.my/6212/1/.

Wan Zaliha Wan Othman \& Amanah bt. Mohd Noor (2015). Kesalahan Ejaan di Papan Tanda. Jurnal Bahasa Memartabatkan Bahasa Melayu MBM(50-57) . Kota Samarahan: IPG Kampus Tun Abdul Razak. 
Wong, S.H. (2015). Tinjauan tentang penggunaan bahasa Melayu dalam buku teks geografi tingkatan satu. Jurnal Penyelidikan, Jilid 12, 1-19. Kuching: Institut Pendidikan Guru Kampus Batu Lintang.

Yong, C.C. \& Vijayaletchumy Subramaniam (2012). Analisis kesilapan dalam pembelajaran bahasa Melayu oleh pelajar asing. GEMA Online ${ }^{\mathrm{TM}}$ Journal of Language Studies. 12(2), 667-692. Dicapai pada 3 Januari 2018,daripada http://journalarticle.ukm.my/4937/1/pp\%2520667_692.pdf.

Zaharani Ahmad (2007). Kekeliruan dalam penggunaan bahasa Melayu: Percanggahan antara rumus tatabahasa dengan korpus bahasa. Jurnal Persatuan Linguistik. Kuala Lumpur: Persatuan Linguistik Malaysia.

Zaharani Ahmad. (2008). Data korpus dan nahu praktis. Dlm. Zaharani Ahmad (pnyt.). Aspek nahu praktis bahasa Melayu, hlm. 15-20. Bangi: UKM.

Zaliza Mohamad Nasir (2017). Kesalahan tatabahasa bahasa Melayu dalam kalangan pelajar. LSP International Journal, 4(1), 23-35. Dicapai pada 3 Januari 2018, daripada

file://C:/Users/WONG\%20SHIA\%20HO/Downloads/44-84-1-SM.pdf. 